RESIDENT

\& FELLOW

SECTION

Section Editor

Mitchell S.V. Elkind,

MD, MS

\title{
Emerging Subspecialties in Neurology: Translational research in movement disorders
}

Sheng-Han Kuo, MD

George R. Jackson, MD, $\mathrm{PhD}$

Address correspondence and reprint requests to Dr. Sheng-Han Kuo, Department of Neurology, Columbia University, $710 \mathrm{~W}$. 168th Street, 3rd floor, New York, NY 10032

sk3295@columbia.edu
Movement disorders constitute a unique field and several characteristics distinguish it from other subspecialties of neurology. Movement disorders specialists rely on clinical phenomenology to generate differential diagnoses and based on a detailed history and neurologic examination, an accurate clinical diagnosis is usually made. Although the pathogenesis of many disorders in the field is not well-understood, therapeutic measures have been developed not only for patient care but also for the exploration of human neuroscience. For example, levodopa use in Parkinson disease (PD) confirms the critical role of dopamine in the disease pathogenesis and deep brain stimulation leads to a better understanding of basal ganglia circuits. These powerful tools provide insights into diseases and also help to illuminate mechanisms of human motor control. In addition, most of the movement disorders clinical practice is outpatient based, and few emergencies exist in this subspecialty, making it an ideal career option for those neurologists seeking to integrate research activities with clinical practice. Historically, many movement disorders specialists have conducted either basic science or clinical research and have made major progress in the field.

TRANSLATIONAL RESEARCH IN MOVEMENT DISORDERS Translational research is defined as "the transfer of new understandings of disease mechanisms gained in the laboratory into the development of new methods for diagnosis, therapy, and prevention and their first testing in humans." Translational research in movement disorders can mainly be divided into 3 domains: basic science research, human motor control, and clinical trials. The basic science aspect involves studying human diseases in animal models by genetic engineering or by pharmacologic manipulation to further understand the disease process or to carry out drug screening. Human motor control studies utilize electrophysiologic or imaging tools such as transcranial magnetic stimulation and functional MRI to explore the human neural circuits for movements. The clinical domain of translational research aims to apply the new therapies to human subjects. Several examples demonstrate the success of rapid translation from the bench to bedside. Viral vector mediated growth factor delivery was proven successful in the rat model of PD in the late 1990s and it was recently tested in human subjects with an exciting phase I result. ${ }^{2}$ The studies on the monkey pedunculopontine nuclei in motor control eventually led to the potential new targets for deep brain stimulation for the treatment of PD. ${ }^{3}$

Fellowship training in translational research. Clinical movement disorders fellowships are currently not accredited by the Accreditation Council for Graduate Medical Education or the United Council for Neurologic Subspecialties. Therefore, there is no standard core curriculum. The clinical movement disorders fellowship training at Columbia University can be an example for the training curriculum design. ${ }^{4}$ For physician-scientists who are interested in pursuing training in translational research in movement disorders, a balance between clinical practice and research activity is essential and can be integrated in several different ways. For example, one can complete 1 to 2 years strict clinical training before going on to laboratory-based or clinical research training. Alternatively, a trainee can spend 1 day or $1 / 2$ day of the week in the clinic and devote the rest of the time to research activities over the course of several years. Each fellowship program has different requirements and focuses on different domains of translational research. Therefore, applicants should consider many factors in each individual training program. The funding for translational research fellowships often comes either from clinical programs or from research funding. A trainee can also learn grant-writing skills to prepare for a future academic career. The $\mathrm{K}$ award series is a mentored career development award provided by the NIH to support young investigators working with mentors to achieve successful research careers (http://grants.nih. gov/training/careerdevelopmentawards.htm). Other 
private foundations such as the PD Foundation also provide clinician-scientist training opportunities (http://www.pdf.org/en/grant funding). Despite the decreasing funding from $\mathrm{NIH}$ for PD and the stable funding for dystonia and Huntington disease research in the past 5 years (http://www.nih.gov/ news/fundingresearchareas.htm), NIH has made translational research a priority and 24 Clinical and Translational Science Award programs have been established in academic centers. It is expected that by 2012 , NIH will have a $\$ 500$ million budget for translational research. ${ }^{1}$ Thus, ample potential exists to develop a physician-scientist career in translational research.

Key features of successful translational research career development. Several components are keys to developing a career in translational research. A trainee works with clinical movement disorders experts to gain clinical experience as well as with translational science mentors to develop research interests. Good mentorship for both clinical and research training are essential. ${ }^{5}$ A good balance between clinical practice and research activity is also a key component. Furthermore, it is also important to seek a supportive environment with a good track record for training successful physician-scientists. Several academic neurology departments in the United States have a long history of training physician-scientists and have integrated programs designed specifically for this purpose.

DISCUSSION Translational research training in movement disorders provides an ideal platform for clinical, scientific, and potential grant writing experience. An academic career in translational research can be very rewarding with the integration of direct investigation of disease process, discovery of new therapies, and advancement of science. Some of the principles in translational research training can also be applied to other subspecialties in neurology. New diagnostic tools and therapeutic measures are rapidly developed and tested on human subjects. Cell transplantation has been tested on patients with PD and Huntington disease. Deep brain stimulation has now been applied more widely to various disorders including medically refractory Tourette syndrome and depression. The ample funding opportunities provided by NIH and PD Foundation encourage young physician-scientists to develop careers in the field. The future of translational research in movement disorders holds promise and offers exciting opportunities to understand human motor control and to advance the treatment of diseases.

\section{DISCLOSURE}

Dr. Kuo serves as an editorial team member for the Resident and Fellow Section of Neurolog $y^{\circledR}$. Dr. Jackson serves on the scientific advisory board of the American Foundation for Aging Research; serves as an editorial board member of the International Journal of Developmental Neuroscience; and receives research support from the NIH [NIH/NINDS/NIA \#R01 NS046489 (PI), NIH/NIA \#P50 AG16570 (Subproject PI), NIH/ NIEHS \#P50 (Subinvestigator), and NIH/NIEHS \#R01 ES01574 (Subinvestigator)].

\section{REFERENCES}

1. Woolf SH. The meaning of translational research and why it matters. JAMA 2008;9:299:211-213.

2. Marks WJ, Jr., Ostrem JL, Verhagen L, et al. Safety and tolerability of intraputaminal delivery of CERE-120 (adeno-associated virus serotype 2-neurturin) to patients with idiopathic Parkinson's disease: an open-label, phase I trial. Lancet Neurol 2008;7:400-408.

3. Stefani A, Lozano AM, Peppe A, et al. Bilateral deep brain stimulation of the pedunculopontine and subthalamic nuclei in severe Parkinson's disease. Brain 2007;130:15961607.

4. Portera-Cailliau C, Victor D, Frucht S, Fahn S. Movement disorders fellowship training program at Columbia University Medical Center in 2001-2002. Mov Disord 2006;21:479-485.

5. Lee A, Dennis C, Campbell P. Nature's guide for mentors. Nature 2007;447:791-797. 


\title{
Neurology
}

\author{
Emerging Subspecialties in Neurology: Translational research in movement disorders \\ Sheng-Han Kuo and George R. Jackson \\ Neurology $2009 ; 73 ; \mathrm{e} 40-\mathrm{e} 41$ \\ DOI 10.1212/WNL.0b013e3181b388b6
}

This information is current as of August 24, 2009

Updated Information \&

Services

References

Subspecialty Collections

Permissions \& Licensing

Reprints including high resolution figures, can be found at:

http://n.neurology.org/content/73/8/e40.full

This article cites 5 articles, 0 of which you can access for free at: http://n.neurology.org/content/73/8/e40.full\#ref-list-1

This article, along with others on similar topics, appears in the following collection(s):

All Movement Disorders

http://n.neurology.org/cgi/collection/all_movement_disorders

Huntington's disease

http://n.neurology.org/cgi/collection/huntingtons_disease

Motor Control

http://n.neurology.org/cgi/collection/motor_control

Parkinson's disease/Parkinsonism

http://n.neurology.org/cgi/collection/parkinsons_disease_parkinsonism

Information about reproducing this article in parts (figures,tables) or in its entirety can be found online at:

http://www.neurology.org/about/about_the_journal\#permissions

Information about ordering reprints can be found online:

http://n.neurology.org/subscribers/advertise

Neurology ${ }^{\circledR}$ is the official journal of the American Academy of Neurology. Published continuously since 1951, it is now a weekly with 48 issues per year. Copyright . All rights reserved. Print ISSN: 0028-3878. Online ISSN: 1526-632X.

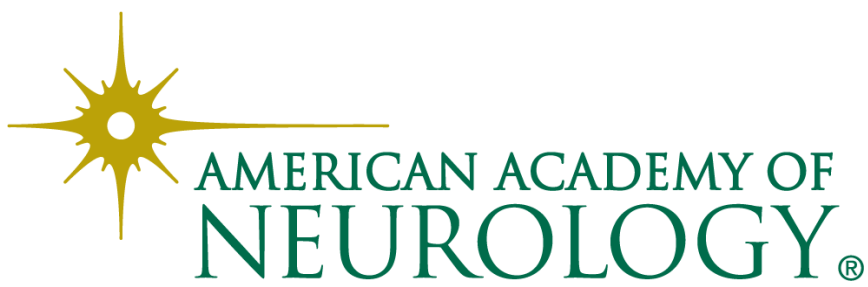

